\title{
Soil susceptibility to compaction under use conditions in southern Brazil
}

\section{Susceptibilidade do solo à compactação sob condições de uso no sul do Brasil}

\author{
Michael Mazurana ${ }^{1 *}$, Renato Levien ${ }^{1}$, Alberto Vasconcellos Inda Junior ${ }^{1}$, \\ Osmar Conte ${ }^{2}$, Luiz Antônio Bressani ${ }^{3}$, Jonatan Müller ${ }^{4}$
}

\author{
${ }^{1}$ Universidade Federal do Rio Grande do Sul/UFRGS, Departamento de Solos, Porto Alegre, RS, Brasil \\ ${ }^{2}$ Empresa Brasileira de Pesquisa Agropecuária/Embrapa, Embrapa Soja, Londrina, PR, Brasil \\ ${ }^{3}$ Universidade Federal do Rio Grande do Sul/UFRGS, Departamento de Engenharia Civil, Porto Alegre, RS, Brasil \\ ${ }^{4}$ Instituto Federal de Educação, Ciência e Tecnologia do Rio Grande do Sul, Bento Gonçalves, RS, Brasil \\ *Corresponding author: michael.mazurana@gmail.com \\ Received in July 4, 2016 and approved in October 6, 2016
}

\begin{abstract}
The degree of soil compaction is intensified by its inadequate management, compaction being variable depending on soil type since even under identical management conditions, different types have different abilities to withstand load. The objective of this study was to evaluate the susceptibility to compaction of different classes of soils under no-tillage (NT) croping system compared to the original condition. Thus, i) soils with the same source material have distinct resistance to compression with increased NT adoption time; ii) the most sensitive indicators of this change are the ratios mass:volume and volume:volume and; iii) there is a relationship between resistance and compaction susceptibility with the amount and type of oxide. Soil samples were collected in areas under NT and under natural condition in order to assess the impact imposed by the NT on the attributes density and porosity, precompression stress and compressibility index and relate them to the oxide type of, and content in, the soils under study. The results show that the density and macroporosity were those most affected by the NT agricultural use, regardless of soil type, that is, its dynamic is related more to soil use and less to mineralogical characteristics. The soil resistance and compaction susceptibility were higher in soil developed in basalt, followed by those developed in sandstone and granite. Both the organic matter content and type and concentration of iron oxides were related to the soil resistance and susceptibility to compaction.
\end{abstract}

Index terms: Soil load-bearing capacity; minerals; organic matter.

\begin{abstract}
RESUMO
O grau de compactação do solo é intensificado pelo seu inadequado manejo, sendo a compactação depente do tipo de solo, uma vez que mesmo sob condições idênticas de uso, diferentes solos têm diferentes habilidades para suportar a carga. O objetivo deste estudo foi avaliar a susceptibilidade à compactação de diferentes classes de solos sob sistema plantio direto (PD) em relação ao estado original. Assim, i) solos com o mesmo material de origem apresentam distinta resistência à compressão com o aumento do tempo adopção do PD; ii) os indicadores mais sensíveis desta mudança são os da relação massa: volume e volume: volume e; iii) existe uma relação entre resistência e suscetibilidade à compactação com a quantidade e o tipo de óxido. As amostras de solo foram coletadas em áreas sob PD e sob condição natural (CN), a fim de avaliar o impacto imposta pelo PD sobre os atributos densidade e porosidade, tensão de précompressão e índice de compressibilidade e relacioná-los com o tipo de óxido e conteúdo. Os resultados mostram que a densidade e a macroporosidade foram os mais afetados pelo uso agrícola em PD, independentemente do tipo de solo, ou seja, a sua dinâmica está mais relacionada com o uso do solo e menos com as características mineralógicas. A resistência do solo e suscetibilidade à compactação foram maiores no solo desenvolvido em basalto, seguido por aqueles desenvolvidos em arenito e granito. Tanto o teor de matéria orgânica e tipo e concentração de óxidos de ferro foram relacionados com a resistência do solo e susceptibilidade à compactação.
\end{abstract}

Termos para indexação: Capacidade de suporte de carga; minerais; matéria orgânica.

\section{INTRODUCTION}

In southern Brazil soils of the classes of Latosols, Argisols, Cambisols and Nitosols have been intensively used for agriculture, livestock and agriculture-livestock integration systems leading, in many cases, to soil compaction problems. This process occurs by human action, when a volume of unsaturated soil is subjected to the action of external force greater than the soil structure can support, deforming it (Horn, 1988). In the agricultural context, the reduction of the pore volume has been assigned to the static and dynamic pressures on the soil imposed by machines (soil-tire interface) when they work under water content conditions above the soil friability condition (Horn et al., 1995).

Such alterations in soil structure are spread to the crops and there is great difficulty observing and 
establishing a cause-effect relationship. This is because the compression can not be considered as a value of a single variable, but as the integration and understanding of a set of variables defining a degree of compression, tolerable or not, by the plant. Variables such as bulk density, pore distribution and arrangement, water content, permeability to air and/or water, soil resistance and structure (Horn et al., 1995; Jung et al., 2010; Peng et al., 2012), its development (Bengough et al., 2006; Jung et al., 2010), morphology and root physiology (Bengough et al., 2006; Lipiec et al., 2012), and the development and performance of the aerial part (Jung et al., 2010; Botta et al., 2010) are some of the indicators that help in understanding the degree of compaction.

Although the compression process is the same for different types of soils, the soils can differ in resistance and resilience. Resistance is the ability of soil to withstand the pressure applied by the external load without losing its structural quality. This attribute is influenced by the proportion and composition of the components of the solid fraction (Ajayi et al., 2009b), as well as by the variation in soil water content, which alters the cohesion and adhesion forces between particles (Hillel, 2004). Resilience can be defined as the intrinsic capacity of the soil to return to its equilibrium state or a new state, after some form of disturbance (for example, pressure application) (Blanco; Lal, 2010). In this case, soil acts as a capacitor, storing energy and matter and adapting to the changes imposed by management.

Studies on the relationship between resistance and susceptibility to soil compaction and mineralogical attributes indicate that, for the same matric potential, there were differences in load bearing capacity and compaction susceptibility when comparing hematitic Latosols with goethitic (Ajayi et al., 2009a,b). Ferreira, Fernandes and Curi (1999) also showed that the density and porosity, associated with structure, may be influenced by clay mineralogy, indicating that this is an important factor to be considered in studies of this nature.

Together with the mineral fraction, the organic fraction has an important role in soil resistance and resilience dynamics, for being connected to the soil aggregation process (Tisdall; Oades, 1982). However, the mechanisms of this organo-mineral interaction are complex, since the increase in organic matter content increases the aggregate stability and therefore the resistance, but reduces the bulk density and increases water retention, both factors that act to reduce resistance to external pressures (Ekwue, 1990; Zhang; Horn; Hallett, 2005; Kuan et al., 2007).

There are few studies that seek to relate the dynamics and physical-mechanical characteristics of the soil with its mineralogical composition, and to identify indicators sensitive alterations imprinted into the soil by management

Thus, the objective of this study was to evaluate the resistance to compression of different soils under no-tillage (NT) compared to the original condition. Thus, i) soils with the same source material have different resistance to compaction due to changes in the physical properties of the soil mass imprinted during the NT adoption time; ii) the most sensitive indicators of this change are the ratios mass:volume and volume:volume and; iii) there is a strict relationship between resistance and susceptibility to compaction, amount and type of oxide present in the soil.

To test these hypotheses, we measured soil parameters such as precompression stress, compressibility index, density, macro and microporosity, the organic matter content and type and concentration of iron oxides of the soil samples.

\section{MATERIAL AND METHODS}

Samples were collected from six classes of soils occurring in the state of Rio Grande do Sul (Table 1) under two use situations, farmed (FMD) and natural condition $(\mathrm{CN})$ and from layers ( 0.0 to 0.10 and 0.10 to $0.20 \mathrm{~m})$. All sampled farmlands are managed under no-tillage (NT) with crop rotation/ succession with a minimum system adoption time five years and a maximum of seven (Table 1). For the natural condition, the fields were located at a similar elevation and at a distance less than 50 meters from the farmed condition. With the exception of the areas whose soils are typical Distroferric Red Nitosol (RNdf) and typical Distroferric Red Latosol (RLdf-1) that had woods, the others had prostrate vegetation, composed mainly of Poaceae.

The soil classes were selected considering the source material, the area of coverage and agricultural importance in terms of use for the production of food, fiber and energy in these regions.

In each soil class we collected samples, with preserved structure, with volumetric cylinders (63 x 25 $\mathrm{mm}$, diameter and height, respectively) at three sites within each use condition and at two depths, totaling 72 sampling points. These cylinders were collected at a depth of 5-7.5 $\mathrm{cm}$ and 15-17.5 $\mathrm{cm}$ (within 0-10 and 10-20 cm layers, respectively) thus seeking to represent the entire layer. Furthermore, disturbed soil samples were collected from each layer to determine soil organic matter. The particle size distribution analysis, particle density, Atterberg limits and mineralogical identification of the soil were carried out in a single soil sample from the 0.0 to $20 \mathrm{~cm}$ layer. 
Table 1: Soil class sampling sites.

\begin{tabular}{|c|c|c|c|c|}
\hline \multirow{2}{*}{ Classes } & \multirow{2}{*}{ Crop sequence } & \multicolumn{2}{|c|}{ Geographical coordinates and altitude } & \multirow{2}{*}{$\begin{array}{c}\text { Material of } \\
\text { origin }\end{array}$} \\
\hline & & Natural condition & Farmed & \\
\hline $\mathrm{CHa}$ & $\begin{array}{c}\text { Soybean/oats+ryegrass/soybean/ } \\
\text { oats + ryegrass/corn/oats }\end{array}$ & $\begin{array}{c}28^{\circ} 28^{\prime} 62^{\prime \prime} \mathrm{S} ; 50^{\circ} 37^{\prime} 43^{\prime \prime} \mathrm{W} \\
958 \mathrm{~m}\end{array}$ & $\begin{array}{c}28^{\circ} 28^{\prime} 72^{\prime \prime} \mathrm{S} ; 50^{\circ} 37^{\prime} 02^{\prime \prime} \mathrm{W} ; \\
962 \mathrm{~m}\end{array}$ & Basalt \\
\hline RLdf-2 & $\begin{array}{l}\text { Oats+ ryegrass/soybean/oats+ } \\
\text { ryegrass/corn/oats + ryegrass }\end{array}$ & $\begin{array}{c}28^{\circ} 34^{\prime} 20^{\prime \prime} \mathrm{S} ; 51^{\circ} 32.02^{\prime \prime} \mathrm{W} \\
618 \mathrm{~m}\end{array}$ & $\begin{array}{c}28^{\circ} 34^{\prime} 24^{\prime \prime} \mathrm{S} ; 51^{\circ} 32^{\prime} 05^{\prime \prime} \mathrm{W} ; \\
601 \mathrm{~m}\end{array}$ & Basalt \\
\hline RAd & $\begin{array}{l}\text { Oats/soybean/oats/corn/oats/ } \\
\text { soja/forage turnip/corn }\end{array}$ & $\begin{array}{c}30^{\circ} 05^{\prime} 41^{\prime \prime} \mathrm{S} ; 51^{\circ} 40^{\prime} 28^{\prime \prime} \mathrm{W} \\
47 \mathrm{~m}\end{array}$ & $\begin{array}{c}30^{\circ} 05^{\prime} 39^{\prime \prime} \mathrm{S} ; 51^{\circ} 40^{\prime} 28^{\prime \prime} \mathrm{W} \\
45 \mathrm{~m}\end{array}$ & Granite \\
\hline RNdf & $\begin{array}{l}\text { Corn/oats+ryegrass(pasture)/ } \\
\text { corn/oats+ryegrass/corn }\end{array}$ & $\begin{array}{c}29^{\circ} 34^{\prime} 69^{\prime \prime} \mathrm{S} ; 51^{\circ} 51^{\prime} 79^{\prime \prime} \mathrm{W} ; \\
39 \mathrm{~m}\end{array}$ & $\begin{array}{c}29^{\circ} 34^{\prime} 68^{\prime \prime} \mathrm{S} ; 51^{\circ} 52^{\prime} 78^{\prime \prime} \mathrm{W} \\
39 \mathrm{~m}\end{array}$ & Sandstone \\
\hline RLd & $\begin{array}{c}\text { Soybean/oats+ryegrass/ } \\
\text { soybean/oats+ryegrass/soybean }\end{array}$ & $\begin{array}{c}28^{\circ} 50^{\prime} 76^{\prime \prime} \mathrm{S} ; 53^{\circ} 29^{\prime} 73^{\prime \prime} \mathrm{W} \\
419 \mathrm{~m}\end{array}$ & $\begin{array}{c}28^{\circ} 50^{\prime} 76^{\prime \prime} \mathrm{S} ; 53^{\circ} 29^{\prime} 73^{\prime \prime} \mathrm{W} \\
420 \mathrm{~m}\end{array}$ & Sandstone \\
\hline RLdf-1 & $\begin{array}{l}\text { Soybean/forage turnip/corn/ } \\
\text { oats/soja/forage turnip }\end{array}$ & $\begin{array}{c}28^{\circ} 16^{\prime} 07^{\prime \prime} \mathrm{S} ; 54^{\circ} 13^{\prime} 36^{\prime \prime} \mathrm{W} ; \\
296 \mathrm{~m}\end{array}$ & $\begin{array}{c}28^{\circ} 15^{\prime} 84^{\prime \prime} \mathrm{S} ; 54^{\circ} 13^{\prime} 43^{\prime \prime} \mathrm{W} \\
290 \mathrm{~m}\end{array}$ & Basalt \\
\hline
\end{tabular}

RLdf-1 = typical dystroferric Red Latosol; RLdf-2 = Distroferric Red Latosol humic; RLd = typical dystrophic Red Latosol; RNdf = Distroferric Red Nitosol; RAd = dystrophic Red Argisol; $\mathrm{CHa}=$ humic aluminic Cambisol.

Cylinders with soil were equilibrated at a $6 \mathrm{kPa}$ voltage on a voltage table to constant weight and weighed before starting the uniaxial compression tests. Each sample was subjected to a sequential load with normal pressure $(\sigma)$ of $12.5 ; 25 ; 50 ; 100 ; 200$ and $400 \mathrm{kPa}$ in a Wykeham Farrance oedometer Wykeham Farrance Eng. Ltd, Slough, England by adapting the methodology described by NBR 12007/90 (ABNT, 1990) in the the 'applied load amount reduction' category. This reduction in the load amount was proposed based on the fact that in Brazil, currently, there are no agricultural machines that apply pressure higher than $400 \mathrm{kPa}$ applied. Each pressure was applied for five minutes (total 30 minutes) and displacement (accuracy of $\pm 0.01 \mathrm{~mm}$ ) recorded at the end of each pressure. After the end of each load sequence, samples were placed to dry in an oven at $105{ }^{\circ} \mathrm{C}$ for $72 \mathrm{~h}$ to determine water content and mass of solids. Data obtained were run in the Compress software for determining the precompression stress and compressibility index. For this, we adjusted the parameters $m$ and $n$ by the van Genuchten equation and the compression curve by the method of Silva Pacheco.

The soil particle size, consistency states (Atterberg limits) and particle density were determined according to Embrapa (1997). The iron related to the pedogenic iron oxides (Fed - iron dithionite) was extracted by dithionitecitrate-bicarbonate at $80^{\circ} \mathrm{C}$ in two successive extractions according to the methodology described by Mehra and Jackson (1960). The iron in the low crystalline iron oxides
(Feo - iron oxalate), was extracted with $0.2 \mathrm{~mol} \mathrm{~L}^{-1}$ ammonium oxalate, $\mathrm{pH} 3$, in the dark (Schwertmann, 1964). Iron content solubilized in each extractor were determined by atomic absorption spectroscopy.

The $\mathrm{x}$-ray diffraction (Siemens D 5000 diffractometer, $\mathrm{CuK} \alpha$ radiation, Ni filter, voltage 40 $\mathrm{kVA}$, current $25 \mathrm{~mA}$ ) was performed in the iron-free clay and concentrated iron fractions. After clay collection via sedimentation, it was flocculated with a $0.1 \mathrm{~mol} \mathrm{~L}^{-1} \mathrm{HCl}$ solution, washed with ethanol/water 1:1 and dried in an oven at $60^{\circ} \mathrm{C}$. The concentrated iron fraction was obtained by treating the clay fraction with a hot $5 \mathrm{~mol} \mathrm{~L}^{-1} \mathrm{NaOH}$ solution, (Kämpf; Schwertmann, 1982). Non-oriented slides of the iron-free clay fraction (from 2 to $72^{\circ} 2 \theta$ ) and the concentrated iron fraction (from 2 at $72^{\circ} 2 \theta$ ) were analyzed, identification of minerals conducted according to the data contained in Brown and Brindley (1980).

To verify changes in the soil for NT adoption, we carried out a comparative analysis of the parameters density and soil porosity, within each soil type. For this purpose, the percentage difference between the NT and the original field condition was computed before conversion to cropland as follows:

[(No-tillage system - natural condition)/natural condition] x 100

The numerical difference percentage indicates a higher or lower percentage of the parameter evaluated in NT compared to the natural condition. This percentage 
difference was used to produce the statistical significance tests using the Wilcoxon Signed Rank Test.

For the variables, precompression stress and compressibility index, each data set for each soil class was submitted to analysis of variance, comparing land use conditions. Later, seeking to identify if the soils are similar in terms of load-bearing and susceptibility to compaction, joint analysis of soils was then conducted. Therefore, each soil was considered as one experiment. Based on the ratio between the highest and the lowest Mean Squared Error (MSE) value of these variables, among the soils, joint analysis was conducted, since this ratio was within the limits acceptable to the statistics. Furthermore, we conducted regression analysis relating the physical, mechanical and mineralogical variables seeking to verify possible links among the selected variables using SAS Software.

\section{RESULTS AND DISCUSSION}

The Table 2 shows the physical and mineralogical characterization of soils. Considering all soils, clay content varied between 0.22 and $0.72 \mathrm{~kg} \mathrm{~kg}^{-1}$, where soils developed from basalt presented vairation from 0.46 to $0.72 \mathrm{~kg} \mathrm{~kg}^{-1}$, and those from sandstone, 0.22 to $0.45 \mathrm{~kg} \mathrm{~kg}^{-1}$.

The X-ray diffraction analysis of the iron-free clay fraction indicated a mineralogical similarity among soils, with a predominance of the clay mineral kaolinite (Figure 1a). On the other hand, the diffraction of the concentrated iron oxide fraction indicated significant soil diversity (Figure 1b) regarding the oxide type, which ranged from hematite soils (RLdf-1, RNdf, Red Latosol - RLd) goethitic (humic aluminic Cambisol - $\mathrm{CH}$ ) and intermediate (humic distroferric Red Latosol - RLdf-2 and dystrophic Red Argissoil - RAd) according to the
Goethite and Hematite ratios $\mathrm{Gt} /(\mathrm{Gt}+\mathrm{Hm})$ (Table 2). The variation of pedogenic iron oxides among soils are also expressed in the total concentration of these minerals (Fed), with a range between $11.5 \mathrm{~g} \mathrm{~kg}^{-1}$ in RLd to $118.1 \mathrm{~g}$ $\mathrm{kg}^{-1}$ in RLdf-1; and the concentration of low crystallinity iron oxides (Feo), which ranged from $0.8 \mathrm{~g} \mathrm{~kg}^{-1}$ in RLd to $8.7 \mathrm{~g} \mathrm{~kg}^{-1}$ RLdf-2 (Table 2). The reason Feo/Fed indicated predominance of crystalline forms of oxides (hematite and goethite), with the exception of RAd soil, where low crystallinity types, such as ferrihydrite, made up 24\% of all pedogenic iron oxides.

According to Ajayi et al. (2009a, b) the variation in the soil solid fraction composition, as observed in the data (texture, mineralogy and particle density), is related to the soil ability to withstand applied external pressure, i.e. with resistance or susceptibility to compaction. This is due to the fact that attributes such as soil density, porosity, pore distribution and shape and soil structure are closely related to the composition of the solid matrix, as pointed out by Ohu, Ragavan and Mckyes (1986), Horn et al. (1988) and Hillel (2004), and the history of management carried out on the soil (Derpsh et al., 2014). These characteristics directly and indirectly affect the mechanical behavior of soils when subjected to machine and animal traffic.

The change in the use of soils studied/investigated led to changes in their structure and consequently to some of their characteristics and properties, particularly in the first $10 \mathrm{~cm}$. For most of the NT soil, the density value increased, while the macroporosity was reduced (Table 3, Figure 2), confirming Horn et al. (1995), Jung et al. (2010) and Peng et al. (2012), who indicate that these are sensitive indicators of changes imposed on the soil by the management. On the other hand, the change in the soil use also led to changes in microporosity values, but of a lower magnitude than those observed for macroporosity.

Table 2: Physical and mineralogical characterization of soils.

\begin{tabular}{|c|c|c|c|c|c|c|c|c|c|c|}
\hline \multirow{2}{*}{ Soil class } & Sand & Silt & Clay & $D_{p}$ & Feo & Fed & \multirow{2}{*}{$\begin{array}{l}\text { Feo/ } \\
\text { Fed }\end{array}$} & $\mathrm{HmFe}$ & GtFe & \multirow{2}{*}{$\begin{array}{c}\mathrm{Gt} / \\
(\mathrm{Gt}+\mathrm{Hm})\end{array}$} \\
\hline & & $\mathrm{kg} \mathrm{kg}^{-1}$ & & $\mathrm{~g} \mathrm{~cm}^{-3}$ & & & & \multicolumn{2}{|c|}{$\mathrm{g} \mathrm{kg}^{-1}$} & \\
\hline RLdf-1 & 0.06 & 0.22 & 0.72 & 2.67 & 4.9 & 118.1 & 0.04 & 113.2 & 0.0 & 0.00 \\
\hline RLdf-2 & 0.18 & 0.35 & 0.47 & 2.63 & 8.7 & 111.4 & 0.08 & 41.1 & 61.6 & 0.60 \\
\hline RLd & 0.76 & 0.02 & 0.22 & 2.56 & 0.8 & 11.5 & 0.07 & 2.2 & 2.2 & 0.21 \\
\hline RNdf & 0.42 & 0.13 & 0.45 & 2.47 & 4.0 & 33.5 & 0.12 & 29.5 & 0.0 & 0.00 \\
\hline RAd & 0.54 & 0.21 & 0.25 & 2.60 & 3.2 & 13.4 & 0.24 & 5.2 & 5.0 & 0.49 \\
\hline $\mathrm{CHa}$ & 0.28 & 0.26 & 0.46 & 2.47 & 3.0 & 34.1 & 0.09 & 0.0 & 31.1 & 1.00 \\
\hline
\end{tabular}

RLdf-1 = typical dystroferric Red Latosol; RLdf-2 = Distroferric Red Latosol humic; RLd = typical dystrophic Red Latosol; RNdf = distroferric Red Nitosol; RAd = dystrophic Red Argisol; $\mathrm{CHa}=$ humic aluminic Cambisol; $\mathrm{D}_{\mathrm{p}}=$ Particle density; $\mathrm{HmFe}=\mathrm{Hematite}$ Iron $(100-((F e d-F e o) \times$ ratio $\mathrm{Gt} /(\mathrm{Gt}+\mathrm{Hm})) ; \mathrm{GtFe}=$ Goethite Iron ((Fed-Feo) $x$ ratio $\mathrm{Gt} /(\mathrm{Gt}+\mathrm{Hm})$. 

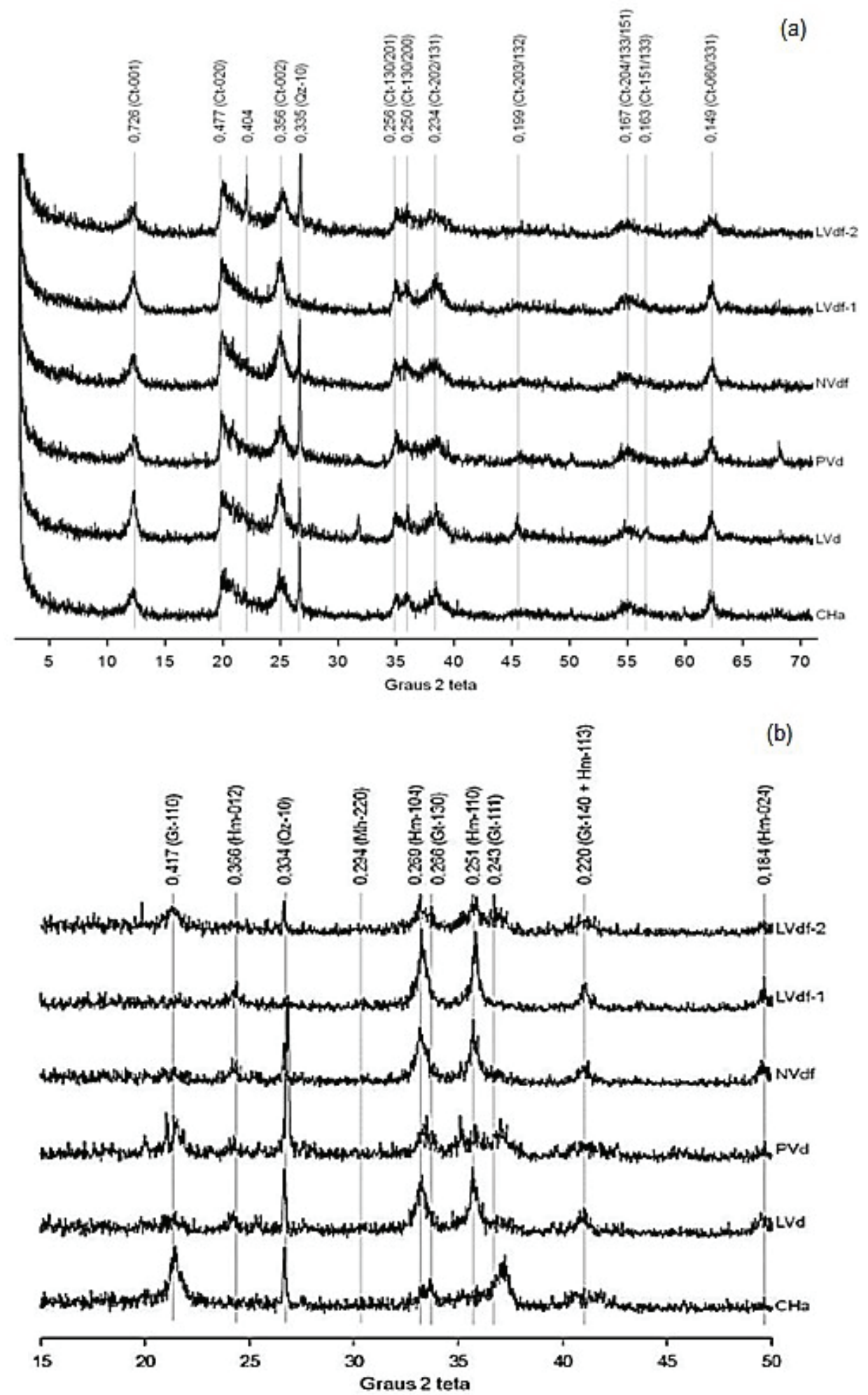

Figure 1: X-ray diffractometry of free clay (a) and concentrated iron (b) fractions of in the 0.0 to 0.20 m layer of the studied soil classes. 
Table 3: Variation in density and porosity of the soil under the use conditions: no-tillage versus the natural condition.

\begin{tabular}{|c|c|c|c|c|}
\hline \multirow[t]{2}{*}{ Soils } & \multirow[t]{2}{*}{ Depth } & $\begin{array}{c}\text { Mean } \\
\text { difference }^{1} \\
(\%)\end{array}$ & Significance & Variation (\%) \\
\hline & & \multicolumn{3}{|c|}{ Density } \\
\hline \multirow{2}{*}{ RAd } & $0-10$ & +14.7 & * & $+10.2-+19.0$ \\
\hline & $10-20$ & -0.8 & Ns & $-0.33-+3.2$ \\
\hline \multirow{2}{*}{ RLd } & $0-10$ & -2.2 & Ns & $-6.8-+1.7$ \\
\hline & $10-20$ & +5.9 & * & $+1.3-+8.6$ \\
\hline \multirow{2}{*}{ RNdf } & $0-10$ & +34.2 & * & $+27.0-+44.5$ \\
\hline & $10-20$ & +8.2 & Ns & $-3.3-+14.4$ \\
\hline \multirow{2}{*}{ RLdf-1 } & $0-10$ & +30.8 & * & $+22.2-+39.1$ \\
\hline & $10-20$ & +14.4 & * & $+10.8-+17.7$ \\
\hline \multirow{2}{*}{ RLdf-2 } & $0-10$ & +11.6 & * & $+2.6-+17.5$ \\
\hline & $10-20$ & +0.15 & Ns & $-1.7-+6.4$ \\
\hline \multirow{2}{*}{$\mathrm{CHa}$} & $0-10$ & +0.72 & Ns & $-0.5-+8.3$ \\
\hline & $10-20$ & -7.2 & * & $-6.2--7.9$ \\
\hline & & \multicolumn{3}{|c|}{ Macroporosity } \\
\hline \multirow{2}{*}{ RAd } & $0-10$ & +207.0 & * & $+136.4-+262.5$ \\
\hline & $10-20$ & +7.0 & Ns & $0.0-+11.1$ \\
\hline \multirow{2}{*}{ RLd } & $0-10$ & -28.8 & $\star$ & $-18.7--41.2$ \\
\hline & $10-20$ & -63.0 & * & $-59.0--68.2$ \\
\hline \multirow{2}{*}{ RNdf } & $0-10$ & -54.3 & * & $-42.8--70.0$ \\
\hline & $10-20$ & -42.5 & * & $-38.4--46.1$ \\
\hline \multirow{2}{*}{ RLdf-1 } & $0-10$ & -45.7 & * & $-40.0--50.0$ \\
\hline & $10-20$ & -34.2 & * & $-30.7--38.4$ \\
\hline \multirow{2}{*}{ RLdf-2 } & $0-10$ & -65.5 & * & $-55.5--77.8$ \\
\hline & $10-20$ & -48.8 & * & $-42.8--60.0$ \\
\hline \multirow{3}{*}{$\mathrm{CHa}$} & $0-10$ & -20.9 & Ns & $-45.4-+10.0$ \\
\hline & $10-20$ & +50.6 & * & $+40-+83.3$ \\
\hline & & \multicolumn{3}{|c|}{ Microporosity } \\
\hline \multirow{2}{*}{ RAd } & $0-10$ & -24.2 & ns & $0.0--36.4$ \\
\hline & $10-20$ & -1.2 & ns & $0.0--3.5$ \\
\hline \multirow{2}{*}{ RLd } & $0-10$ & +4.6 & * & $+4.5-+4.7$ \\
\hline & $10-20$ & +20.4 & * & $+15-+26.3$ \\
\hline \multirow{2}{*}{ RNdf } & $0-10$ & -5.3 & * & $-5.2--5.4$ \\
\hline & $10-20$ & +7.9 & ns & $-9.7-+24.14$ \\
\hline \multirow{2}{*}{ RLdf-1 } & $0-10$ & +4.1 & * & $+2.4-+5.0$ \\
\hline & $10-20$ & +2.7 & ns & $-2.3-+10.5$ \\
\hline
\end{tabular}

Table 3: Continuation...

\begin{tabular}{rrrrc}
\hline RLdf-2 & $0-10$ & +27.6 & $*$ & $+20.4-+38.5$ \\
& $10-20$ & +13.0 & $*$ & $+11.6-+15.9$ \\
$\mathrm{CHa}$ & $0-10$ & +4.80 & $\mathrm{~ns}$ & $0.0-+10.4$ \\
\cline { 2 - 5 } & $10-20$ & +0.69 & $\mathrm{~ns}$ & $-2.0-+2.0$ \\
\hline
\end{tabular}

${ }^{1}$ Positive or negative values refer to natural field as a reference. For example, for the density in RAd, the value is $14.7 \%$ higher in no-tillage compared to the natural condition.

* Significant at $p<0.12$ by the Wilcoxon Signed-Rank test.

This dynamic is related to the type of pores that characterize the pore system, i.e., structural and textural pores (Alaoui; Lipiec; Gerke, 2011), in which the effects of cultivation system affected the former more significantly (Guérif, 1990), originated from the arrangement of microaggregates, while the intra-aggregate pores (textural) are less affected. Alterations at the microaggregate level may occur via soil wetting and drying cycles (Grant et al., 1995) or by high machine and animal traffic frequency under humidity conditions higher than the ground friability condition, even under the NT system. In this case, soil mass deformation, without rupture, leads to a reduction, especially of macroporosity and in some cases, increased microporosity, indicative of low stability aggregates. This corroborates Munkholm and Schjonning (2004), who found that the aggregate structure is affected by the management of very moist soil. Alterations in these characteristics lead to changes in soil water, air and temperature flow dynamics, changes in water storage and redistribution (Lipiec; Hatano, 2003), root system development (Bengough et al., 2006; Jung et al., 2010) with modifications in root syatem physiology and changes in nutrient uptake by plant roots.

The higher variations in the properties evaluated and observed in the first $10 \mathrm{~cm}$ of soil are associated with machine traffic on the farmed land, which still occurs randomly, increasing the trafficked area, unlike a controlled traffic condition where it always occurs in the same location. Furthermore, most mechanized assemblies on the worked properties have diagonal type tires which have a higher tire inflation pressure and transmits more pressure to the soil, as compared to radial tires or those of low pressure and high fluctuation, for the same mass of machine (Mazetto et al., 2004). This greater pressure, associated with a high traffic intensity under humidity conditions higher than the friability range, generates plastic deformations in the soil mass, first at the surface and later in the subsurface (Chamen et al., 2003), significantly altering the parameters evaluated herein. 

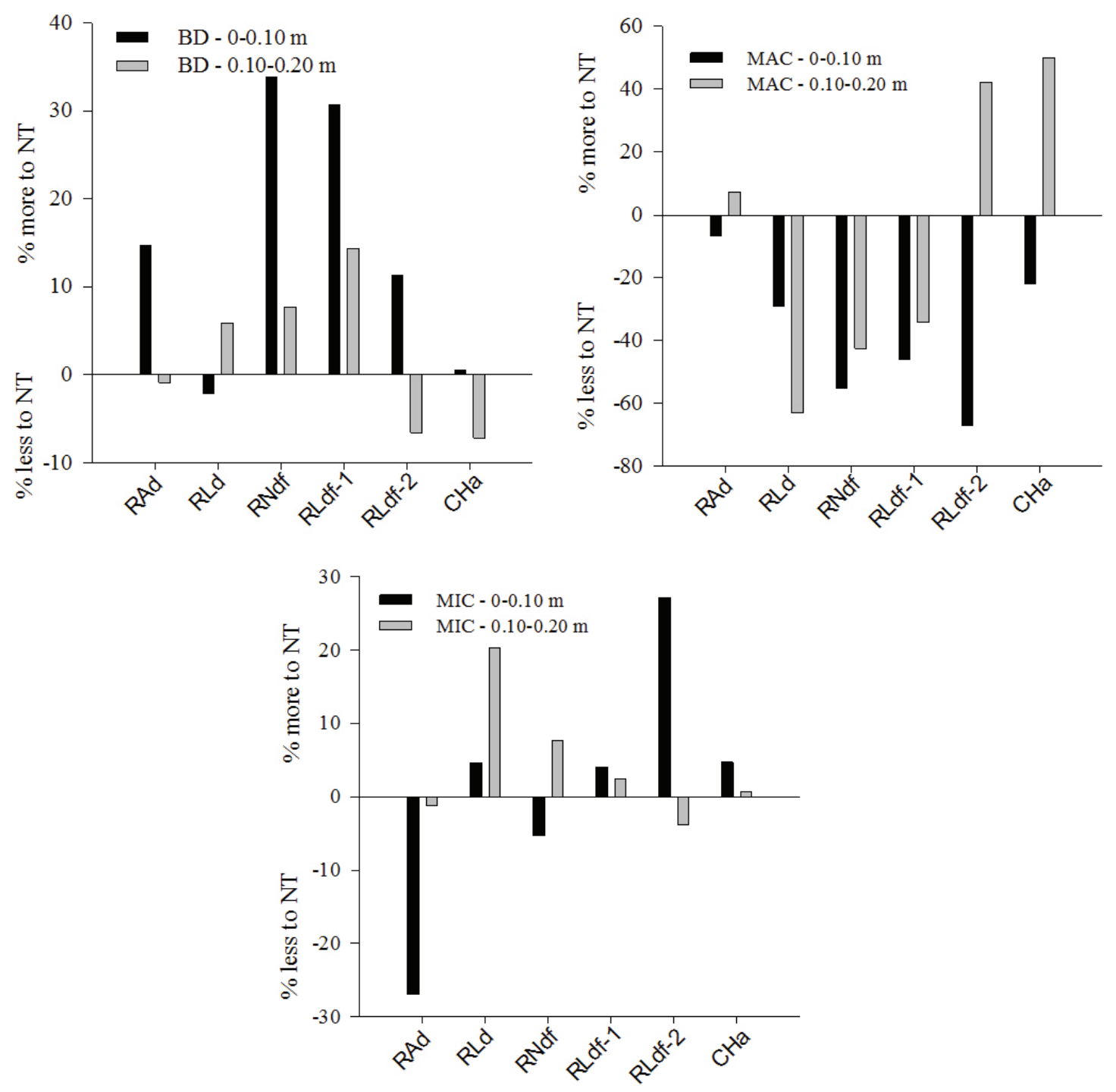

Figure 2: Variation rate of the density and soil porosity values comparing the NT with the natural condition.

When subjected to pressure, the soil can undergo deformation or not. The ability to deform is related to its load bearing capacity, which can be measured based on the precompression stress (Figure 3a), or susceptibility to deformation as measured by the compressibility index (Figure 3b). The soils presented significantly different values $(\mathrm{p}<0.10)$ for both indicators. However, significant differences were observed only for the compressibility index, when analyzing the use condition for the same type of soil, this index being, on average, higher for the natural condition, indicating that this is more susceptible to compaction (Table 4).
The soil load bearing capacity was higher for soils developed in basalt (RLdf-1, RLdf-2 and CH), followed by soils developed in sandstone (RNdf and RLd) and granite (RAd), respectively (Figure $3 \mathrm{a}$ ). These soils originated from basalt had higher clay content, in which the 1:1 type clay mineral (kaolinite) and iron oxides (hematite and goethite) predominated, that act on the formation and stability of microaggregates, providing higher load bearing capacity to soils, even with low matric potential (Ajayi et al., 2009a, b) and providing high total porosity, due to intra-aggregate micropores and meso and macropores. 

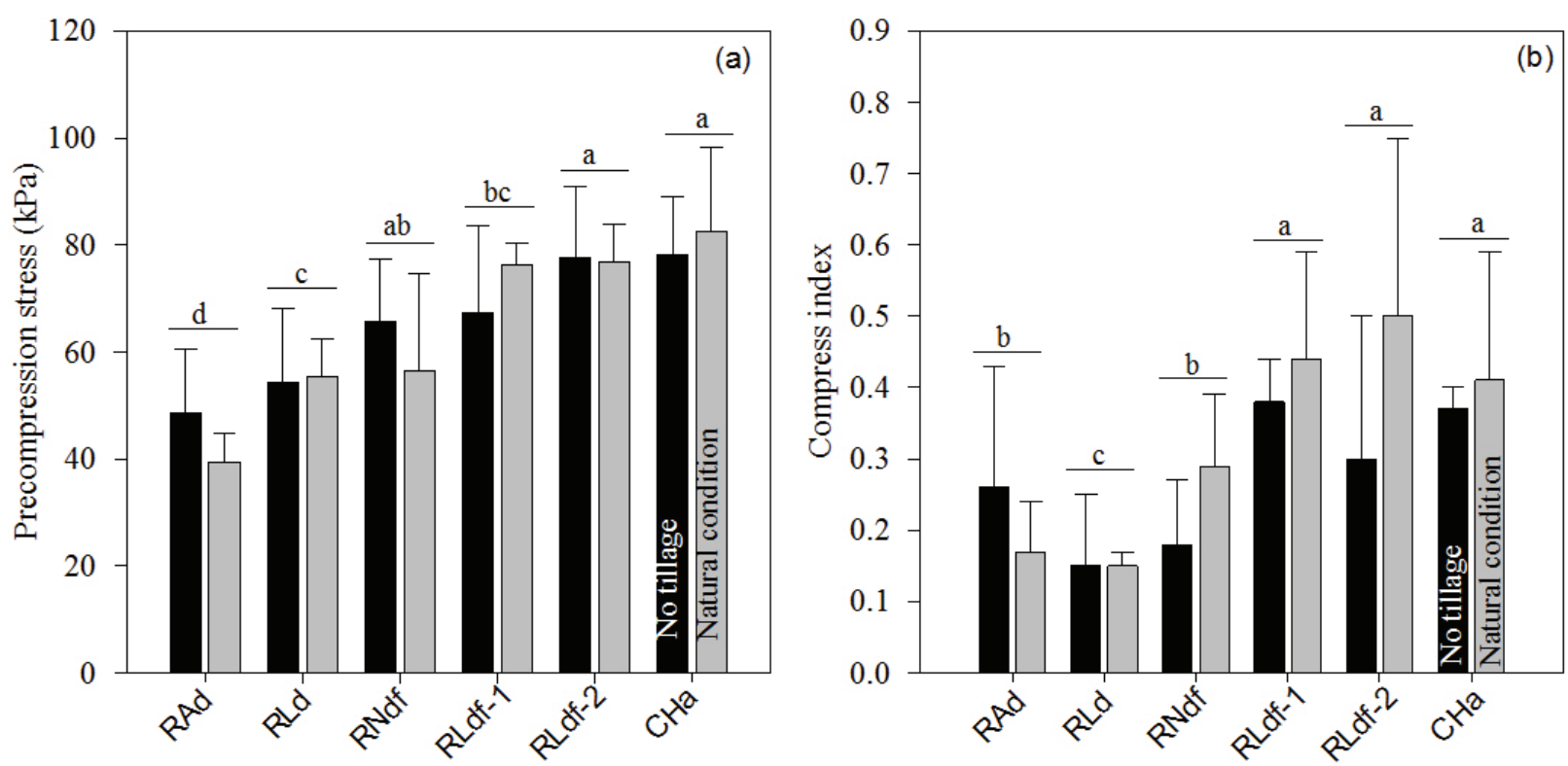

Figure 3: Precompression stress (a) and compressibility index (b) for each soil class and management condition (no-tillage and natural condition) in the $0-20 \mathrm{~cm}$ layer. Letters (the same do not differ significantly by the Duncan test $p<0.10$ ) above the bars compare classes and soils.

Table 4: ANOVA for the joint analysis of experiments (Duncan, $\mathrm{p}<0.1$ ).

\begin{tabular}{cccccc}
\hline \multirow{2}{*}{ Source } & \multirow{2}{*}{ DF } & F-Value & Pr $>F$ & F-Value & Pr $>F$ \\
\cline { 3 - 6 } & 5 & 11.27 & $<0.0001$ & 20.06 & $<0.0001$ \\
Soil class & 5 & 0.04 & 0.8424 & 11.31 & 0.0003 \\
Use conditions & 1 & 1.08 & 0.3792 & 4.72 & 0.0011 \\
\hline
\end{tabular}

Associated with the clay content, the presence of organic matter also assists in the aggregates formation and stability (Tisdall; Oades, 1982), providing these soils greater load support (Table 5) and, at the same time, increased susceptibility to deformation (Figure $3 \mathrm{~b}$, Table 5). This is due the increased organic matter content in the soil leading to a reduction in the initial density and, indirectly, increase porosity, making the soil mass susceptible to deformation (Zhang; Horn; Hallett, 2005; Kuan et al., 2007). However, even being susceptible to new deformation, the organic material has higher elasticity compared to the mineral portion (Soane, 1990), allowing the soil mass to recover its characteristics to near the pre-load condition.

The reduction in the clay content (Figure $4 \mathrm{a}$ ) and organic matter, or even an increase only in organic matter, along with the increase in the other size fractions, can lead to a reduction in the load bearing capacity for different reasons: i) reduction in cohesive forces among particles by the lower electric charge intensity, reduced bond strength and/or absence of new connection establishment (Soane, 1990); ii) a lower specific surface area of the mineral material (Hillel, 2004) and; iii) reduction of the internal angle of friction among particles (Braida et al., 2007), caused by the increase in sand level and organic matter content, and the latter being the cause of the soil density reduction (Ekwue, 1990).

The predominance of kaolinite (Figure 1a), hematite and goethite (Table 2) play an important role in the soil aggregation and structure stability processes. The presence of kaolinite provides a soil microstructure in blocks, according to the face to face arrangement of the layers, unlike that observed for soils (especially Latosols) with predominance of gibbsite in the clay fraction, which provides a granular microstructure (Ferreira; Fernandes; Curi, 1999). This suggests that in predominantly kaolinitic 
soils, the increase in clay content would develop a more bearing capacity, which was observed in the data presented solid microaggregate structure, having greater load-

(Figure 4a and 5).

Table 5: Regression analysis between soil organic matter and physical properties.

\begin{tabular}{cccc}
\hline Variable & Equation & $\mathrm{R}^{2}$ & $\mathrm{P}$ \\
\hline Bulk density & $\mathrm{BD}=1.62-0.0098 \mathrm{SOM}+2.14 \times 10^{-5} \mathrm{SOM}^{2}$ & 0.65 & 0.21 \\
Load-bearing capacity & $\sigma_{\mathrm{p}}=56.21+0.3586 \mathrm{SOM}$ & 0.71 & 0.074 \\
Compressibility index & $\mathrm{lc}=0.12+0.0037 \mathrm{SOM}$ & 0.89 & 0.015 \\
\hline
\end{tabular}
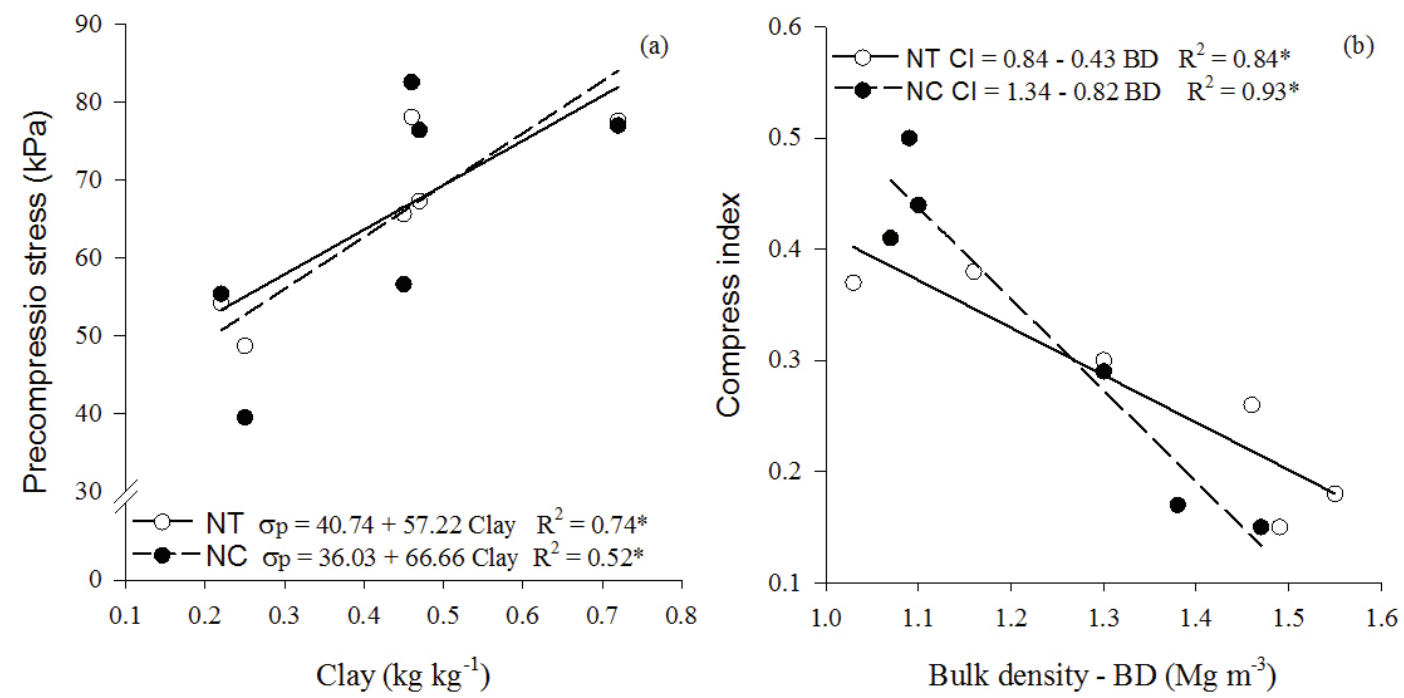

Figure 4: Relationship between precompression stress and clay content (a) and compressibility index and soil density (b)* Significant at $p<0.10$.
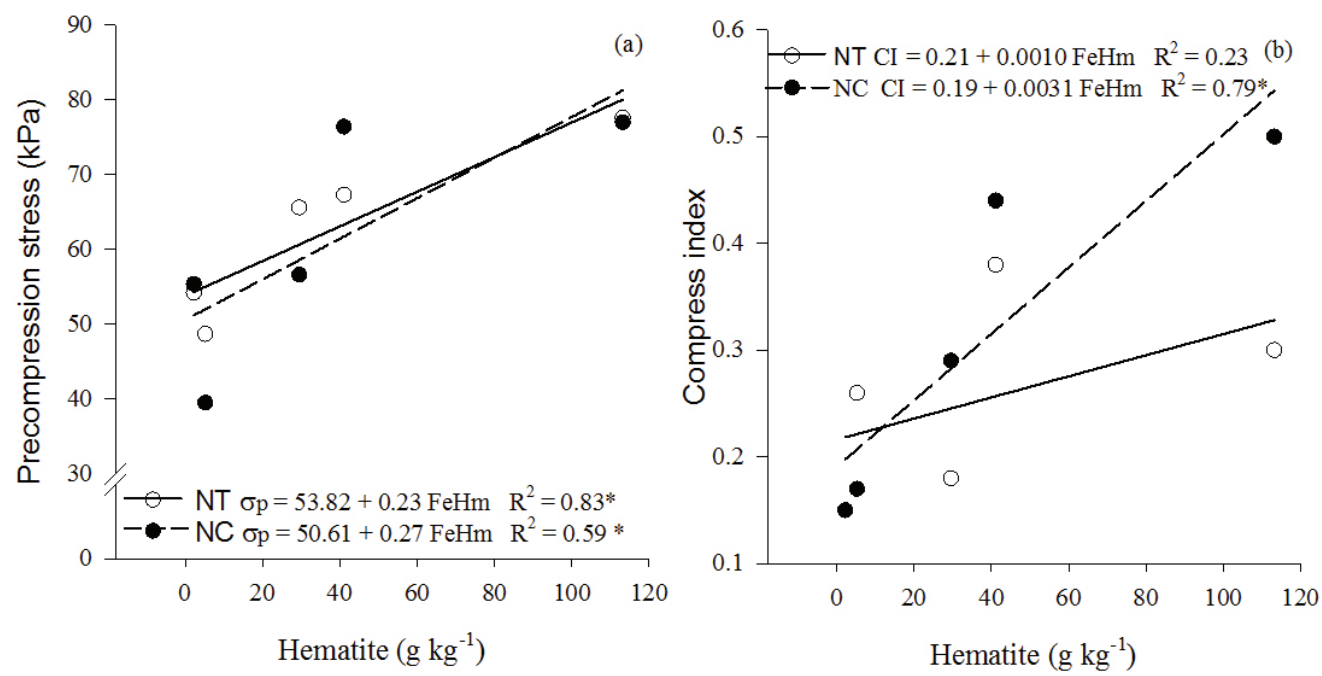

Figure 5: Relationship between precompression stress and hematite content (a) and compressibility index and hematite content (b). * Significant at $p<0.10$. 
Just as for kaolinite, iron and aluminum oxides act indirectly on soil resistance, since they are associated with soil aggregation and structure. Its presence in soil conditions a granular structure, which may or may not influence the density and aggregation (Muggler et al., 1999; Giarola; Silva; Imhoff, 2002). The higher presence of iron oxides (hematite and goethite) usually conditions more stable aggregates, which may be associated with the structure of the mineral, not the characteristics that it imprints on the soil mass as Giarola, Silva and Imhoff (2002) point out. In hematite, for example, there is a uniform packing of the oxygen atoms between one octahedron and another, whereas in the goethite there is no perfect packing between the oxygen atoms of an octahedron and hydrogen of anther, providing different structures to soils with different types and amounts of iron oxides.

In this sense, predominantly goethite soils $(\mathrm{CH})$ and hematite (RLdf-1), as well as those with intermediate amounts of the two types of oxides (RLdf-2), were those with the highest load bearing capacity and increased susceptibility to compression compared to the others analyzed (Table 2, Figure 3a, b). These soils presented a positive correlation with the types and amounts of iron oxides (Table 6). This corroborates results of Ajayi et al. (2009a), which show that, for the same matric potential, Latosols with predominance of hematite have less load bearing capacity when compared to predominantly goethite or gibbsite Latosols.

The relationship between the hematite type iron oxide and precompression stress and compressibility index was positive for both the natural condition and for NT (Figure $5 \mathrm{a}, \mathrm{b})$ not being significant $(\mathrm{p}<0,10)$ only for natural field conditions (Figure $5 b$ ). This suggests that more uniform kaolinite layer packing in soils with hematite predominance is less stable, corroborating the lower load carrying capacity (Table 2, Figure 3a). Distinct dynamics were observed for the same relation when analyzing the relationship with goethite (data not shown because the coefficient of determination is less than 5\%).

Similarly we observed a correlation of the soil density with the oxide type in these soils (Table 6). The negative and significant correlation between soil density and goethite iron oxides is due to the fact that the oxides act as binding agents between the mineral particles that determine soil structure basis (Muggler et al., 1999; Ferreira; Fernandes; Curi, 1999). In such cases, the goethite conditions a more dense packing of mineral particles, providing greater intraaggregate resistance that would allow the soil to present a more stable microstructure, regardless of the moisture condition experimented, confirming Ajayi et al. (2009a).
However, there are few soils with only one type of iron oxide in their mineral matrix. Both oxides (goethite and hematite) are more commonly found in the same environment, but in different proportions. The precompression stress data (Figure 3a) are in line with the previous observation and corroborate Ajayi et al. (2009a), showing that soils with higher iron oxide content of the hematite and goethite type (Table 2, Figure 3a) presented the highest precompression stress values. This indicates there is a close relationship between the mineralogical variables and mechanical variables analyzed herein.

Table 6: Spearman correlation between soil physical, mechanical and mineralogical characteristics.

\begin{tabular}{cccccc}
\hline & Feo & Fed & Feo/Fed & HmFe & GtFe \\
\hline BD & -0.55 & -0.57 & $0.44^{\text {ns }}$ & $-0.23^{\text {ns }}$ & -0.71 \\
$\sigma_{p}$ & $-0.14^{\text {ns }}$ & $0.41^{\text {ns }}$ & -0.65 & $0.42^{\text {ns }}$ & $0.07^{\text {ns }}$ \\
IC & 0.63 & 0.69 & $-0.34^{\text {ns }}$ & $0.47^{\text {ns }}$ & 0.51 \\
\hline
\end{tabular}

BD - Bulk density; $\sigma_{p}$ - Precompression stress; Cl Compressibility index; Feo - Iron oxalate; Fed - Iron dithionite; HmFe - Hematite Iron; GtFe - Goethite Iron; ns - not significant at $p<0.1$.

\section{CONCLUSIONS}

The soil had different load-bearing capacity and compaction susceptibility. For the same type of management, soils with a predominance of hematite presented significant difference between these variables. The physical density and macroporosity parameters were impacted the most by the soil use change. The density increased $40 \%$ and macroporosity reduced $60 \%$ in some soils. Such alterations are signs that gas and water processes may have been altered in these soils. Negative and positive correlation between the type and amount of iron oxide in the soil and the soil density, precompression stress and compressibility index indicate that soil mineralogy has significant influence on the dynamics of these variables. The organic fraction had an influence on the analysis of mechanical parameters, positively confirming the increased load bearing capacity and, with less intensity, the compression ratio.

\section{REFERENCES}

ASSOCIAÇÃO BRASILEIRA DE NORMAS TÉCNICAS - ABNT. Ensaio de adensamento unidimensional: NBR 12007. Rio de Janeiro, 1990. 13 p. 
AJAYI, A. E. et al. Strength attributes and compaction susceptibility of Brazilian Latosols. Soil and Tillage Research. 105:122-127, 2009a.

AJAYI, A. E. et al. Relation of strength and mineralogical attributes in Brazilian Latosols. Soil and Tillage Research. 102:14-18, 2009b.

ALAOUI, A.; LIPIEC, J.; GERKE, H. H. A review of changes in the soil pore system due to soil deformation: A hydrodynamic perspective. Soil and Tillage Research. 115:1-15, 2011.

BENGOUGH, A. G. et al. Root responses to soil physical conditions: Growth dynamics from field to cell. Journal of Experimental Botany. 57:437-447, 2006.

BLANCO, H.; LAL, R. Principles of Soil Conservation and Management. 1.ed. Columbus: Spring Science Business Media B.V, 2010. 617p.

BOTTA, G. F. et al. Tillage and traffic effects (planters and tractors) on soil compaction and soybean (Glycine max L.) yields in Argentinean pampas. Soil and Tillage Research. 110:167-174, 2010.

BRAIDA, J. A. et al. Coesão e atrito interno associados aos teores de carbono orgânico e de água de um solo franco arenoso. Ciência Rural. 37:1646-1653, 2007.

BROWN, G.; BRINDLEY, G. W. X-ray diffraction procedures for clay mineral identification. In: BRINDLEY, G. W.; BROWN, G. (Ed.). Crystal structures of clays minerals and their X-ray identification. 1.ed. London: Mineralogical Society, 1980. p.305-360

CHAMEN, W. T. C. et al. Prevention strategies for field trafficinduced subsoil compaction: A review. Part 2. Equipment and field practices. Soil and Tillage Research. 73:161-174, 2003.

DERPSCH, R. et al. We do we need to standardize no tillage research? Letter to the editor. Soil and Tillage Research. $137: 16-22,2014$

EKWUE, E. I. Organic matter effects on soil strength properties. Soil and Tillage Research. 16:289-297, 1990.

EMPRESA BRASILEIRA DE PESQUISA AGROPECUÁRIA EMBRAPA. Manual de métodos e análise de solo. 2.ed. Rio de Janeiro: CNPS, 1997, 212p.

FERREIRA, M. M.; FERNANDES, B.; CURI, N. Mineralogia da fração argila e estrutura de latossolos da região sudeste do Brasil. Revista Brasileira de Ciência do Solo. 23:507-514, 1999.

GIAROLA, N. F. B.; SILVA, A. P.; IMHOFF, S. Relações entre propriedades físicas e características de solos da região Sul do Brasil. Revista Brasileira de Ciência do Solo. 26:885-893, 2002
GRANT, C. D. et al. An analysis of the fragmentation of remolded soils with regard to self-mulching behavior. Australian Journal of Research. 31:569-583, 1995.

GUÉRIF, J. Factors influencing compaction-induced increases in soil strength. Soil and Tillage Research. 16:167-178, 1990.

HILLEL, D. Introduction to environmental soil physics. 1.ed. Oxford: Elsevier Academic Press, 2004, 494p.

HORN, R. Compressibility of arable land. Catena. 11:53-71, 1988.

HORN, R. et al. Soil compaction processes and their effects on the structure of arable soils and the environment. Soil and Tillage Research. 35:23-36, 1995.

JUNG, K. Y. et al. Soil compaction varies by crop management system over a claypan soil landscape. Soil and Tillage Research. 107:1-10, 2010.

KÄMPF, N.; SCHWERTMANN, U. The $5 \mathrm{M} \mathrm{NaOH}$ concentration treatment for iron oxides in soils. Clays and Clay Minerals. 30:40-408, 1982.

KUAN, H. L. et al. The biological and physical stability and resilience of a selection of Scottish soils to stresses. European Journal Soil Science. 58:811-821, 2007.

LIPIEC, J.; HATANO, R. Quantification of comparison effects on soil physical properties and crop. Geoderma. 116:107-136, 2003.

LIPIEC, J. et al. Effects of soil compaction on root elongation and anatomy of different cereal plant species. Soil and Tillage Research. 121:74-81, 2012.

MAZETTO, F. R. et al. Avaliação do contato pneu-solo para em três modelos de pneus agrícolas. Engenharia Agrícola. 24:750-757, 2004.

MEHRA, O. P.; JACKSON, M. L. Iron oxide removal from soils and clay by a dithionite-citrate system bulfered with sodium bicarbonate. Clays and Clay Minerals. 7:317-327, 1960.

MUGGLER, C. C. et al. Aggregation, organic matter, and iron oxide morphology in Oxisoil from Minas Gerais, Brazil. Soil Science. 164:759-770, 1999.

MUNKHOLM, L. J.; SCHJONNING, P. Structural vulnerability of a sandy loam exposed to intensive tillage and traffic in wet conditions. Soil and Tillage Research. 79:79-85, 2004.

OHU, J. O.; RAGAVAN, G. S. V.; MCKYES, G. Shear strength prediction of compacted soil with varying added organic matter contents. Trans. American Society Agriculture Engineer. 29:351-355, 1986.

PENG, X. et al. Does soil compaction change soil shrinkage behavior? Soil and Tillage Research. 125:89-95, 2012. 
SCHWERTMANN, U. Differenzierung der eisenoxide des bodens durch extraktion mit ammoniumoxalat-lösung. Z. Pflanzenernähr Düng Bodenkd. 105:194-202, 1964.

SOANE, B. D. The role of organic matter in soil compactability: A review of some practical aspects. Soil and Tillage Research. 16:179-201, 1990.
TISDALL, J. M.; OADES, J. M. Organic matter and water-stable aggregates in soils. European Journal of Soil Science. 33:141-163, 1982

ZHANG, B.; HORN, R.; HALLETT, P. D. Mechanical resilience of degraded soil amended with organic matter. Soil Science Society of American Journal. 69:864-871, 2005. 